\title{
Determination of the Size Distribution of Nanoparticles Using Asymmetric Flow Field- flow Fractionation (AF4)
}

\author{
Daisuke Itabashi ${ }^{1)^{*}}$, Reiko Murao ${ }^{1)}$, Shunsuke TAniguchi ${ }^{1)}$, Kazumi MizuKami ${ }^{2)}$, Hideaki TAKAGI $^{3)}$ \\ and Masao KIMURA ${ }^{3,4)}$ \\ 1) Advanced Technology Research Laboratories, Nippon Steel Corporation \\ 2) Nippon Steel Technology Co., Ltd \\ 3) Photon Factory (PF), Institute of Materials Structure Science, High Energy Accelerator Research Organization \\ (KEK) \\ 4) School of High Energy Accelerator Science, SOKENDAI (The Graduate University for Advanced Studies)
}

Abstract: To investigate the performance of the size measurement by asymmetric flow field-flow fractionation (AF4), the measurement results of gold nanoparticles were compared among AF4, transmission electron microscopy (TEM), and small-angle X-ray scattering (SAXS) in terms of the average size and full width at half maximum (FWHM) of the size distribution. Although the average size was almost the same for the three methods, the FWHM measured using AF4 was larger than those measured using TEM and SAXS. This is attributed to the diffusion of the gold nanoparticles inside the AF4 instruments. The broadening factor of AF4 analysis was determined as 2.08 by the average of FWHM ratio of AF4 to TEM measured using the several sphere-like gold nanoparticles. In addition, the effect of particle shape on the above broadening factor was investigated using the sphere-like and plate-like silver nanoparticles. The broadening factor for plate-like particles apparently became smaller than that for sphere-like particles, possibly because the Brownian motion of plate-like particles was suppressed.

Furthermore, the AF4 analysis with the FWHM correction method using the broadening factor was applied to niobium carbide ( $\mathrm{NbC}$ ) precipitates in steels. The average size measured by AF4 was mostly consistent with the results obtained in regions observed by TEM. Moreover, an increase in the number density of nanometer-sized $\mathrm{NbC}$ by heat treatment was successfully detected. The effect of particle shape on FWHM should be further investigated and improved; however, AF4 with the broadening factor can semi-quantitatively analyze the size distribution of nanoprecipitates in steels.

Keywords: asymmetrical flow field-flow fractionation; gold nanoparticles; silver nanoparticles; niobium carbide; size distribution; transmission electron microscopy; small-angle X-ray scattering.

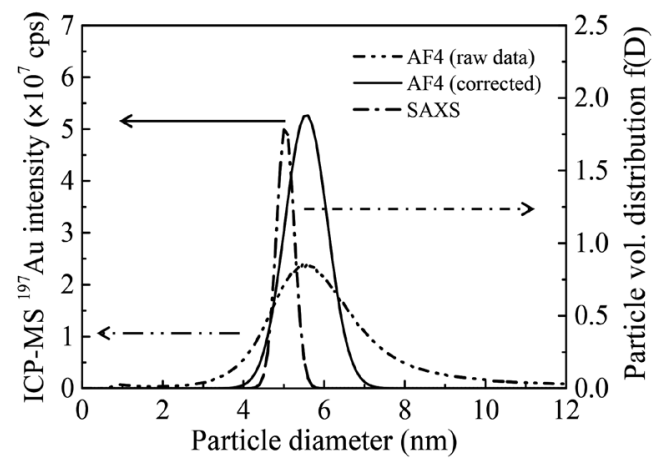

Received on Aug. 18, 2020 ; Accepted on Sep. 14, 2020 ; J-STAGE Advance published on Oct. 30, 2020 ; originally published in ISIJ Int., Vol.60, 2020, No.5, pp.979-987

* Corresponding author. E-mail : itabashi.53b.daisuke@jp.nipponsteel.com, Address : Nippon Steel Corporation, 20-1 Shintomi Futtsu Chiba 293-8511 


\title{
非対称流れ流動場分離 (AF4) 法による ナノ粒子の粒子径分布測定
}

\author{
板橋 大輔 $^{1) *} \cdot$ 村尾 玲子 ${ }^{1)} \cdot$ 谷口 $\quad$ 俊介 ${ }^{1)} \cdot$ 水上 和実 ${ }^{2)} \cdot$ 高木 秀彰 $^{3)} \cdot$ 木村 正雄 $^{3,4}$
}

Determination of the Size Distribution of Nanoparticles Using Asymmetric Flow Field-flow Fractionation (AF4)

Daisuke Itabashi, Reiko Murao, Shunsuke Taniguchi, Kazumi Mizukami, Hideaki Takagi and Masao Kimura

\section{1. 緒言}

近年, 化粧品, 電子機器, 食品等の様々な産業では, 金 $^{1,2)}$, 銀 $^{3)}$, 白金 ${ }^{4)}$ ，カーボンナノチューブ，カーボンブ ラックや量子ドット ${ }^{5)}$ などのナノ粒子を利用して, 製品開 発を行なっている。ここでナノ粒子とは, 直径 1 〜 $100 \mathrm{~nm}$ を有する材料のことを指す。鉄鋼材料の開発においても, ナノメートル〜サブマイクロメートルの粒子径を有する 微粒子を活用して，製品に様々な機械的特性を付与してい る ${ }^{6,7)}$ 。鉄鋼材料中において，これらの微粒子が鋼の機械的 特性に及ぼす影響は，その粒子径と個数密度に依存してい るため，平均粒子径および粒子径分布を正確に測定するこ とが，製品開発やプロセス管理の上では非常に重要にな る。これらの微粒子は幅広い粒子径分布（例えば，数ナ） メートルの粒子と数百ナノメートルの粒子の混合物) を有 していることが多く, 従来の光散乱測定や透過型電子顕微 鏡（transmission electron microscopy; TEM）を用いる場合に は，材料全体の粒子径分布を正確に測定することがしば しば困難となる。さらに，鉄鋼材料中ではこれらの微粒子 は, 様々な形状や化学種で存在しているため, 分析する際 には特に注意を払う必要がある。一般的に複数種類の微粒 子が共存した試料の粒子径を測定する場合，様々な測定方 法において，その測定結果の確からしさが影響を受ける ことは良く知られている。例えば, 動的光散乱法 (dynamic light scattering; DLS $)^{8)}$ の場合, 散乱光の強度は粒子径に強 く依存するため，大きな粒子から散乱された強い光は，小 さな粒子から散乱された弱い光を見かけ上隠蔽する。それ ゆえ，小さな粒子と大きな粒子の混合物を測定する場合に

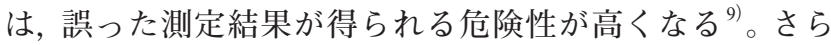

に,DLSで測定される流体力学的直径は球状粒子の平均 直径として見積もられるため, 様々な粒子径や形状を有す る粒子の混合物を正確に測定することは，極めて困難であ る。また, TEM 観察 ${ }^{10)}$ の場合では, 単分散した粒子を観察 することは容易であるが, 異なる粒子径を有する粒子の混 合物の観察では，粒子同士が物理的に重なり合うと，小さ な粒子が大きな粒子に隠されて，しばしば見落とされやす くなり, 結果として䛊った粒子径分布として測定されてし まう。これらの測定方法には，溶液中に分散させた異なる 粒子径を有する粒子の混合物を区別できないという共通の 問題点がある。

したがって，上記のような異なる粒子径を有する粒子の 混合物の粒子径分布を正確に測定するためには, 試料の粒 子径を測定する前に, 何らかの手法でサイズ分離すること が必要となる。サイズ排除クロマトグラフィー ${ }^{11,12)}$, 非対称 流れ流動場分離法 (asymmetric flow field-flow fractionation; $\mathrm{AF} 4)^{13)}$, ハイドロダイナミッククロマトグラフィー ${ }^{13)}$, キャピラリー電気泳動 ${ }^{14)}$, ゲル電気泳動 ${ }^{15)}$, 超遠心分離法 等, 粒子径の違いに基づいた分離分析法が先行研究で多く 報告されている。これらの中でも，多くの報告において， $\mathrm{AF} 4$ は金属ナノ粒子の分析に対して，いくつかの利点を有 していると提唱されており ${ }^{16,17)}$ ，ナノメートルからマイク ロメートルの範囲の様々な試料に対して, 系に共存する溶 媒, 界面活性剤, 塩等のマトリックスの有無によらず, 適 用されている。AF4 DLS や誘導結合プラズマ質量分析法 (inductively coupled plasma-mass spectrometry; ICP-MS) と組 み合わせると, 測定試料の粒子径分布およびその元素組成 を決定することができる ${ }^{18-20)}$ 。したがって, AF4は不均一 で幅広い粒子径分布を持つ粒子 (例えば, 鉄鋼材料中の析

原著論文 : ISIJ Int., Vol.60 (2020), No.5, pp.979-987

2020年 8 月 18 日受付 2020年9月14日受理２020年10月30日J-STAGE早期公開 (Received on Aug. 18, 2020 ; Accepted on Sep. 14, 2020；J-STAGE Advance published on Oct. 30, 2020 ; originally published in ISIJ Int., Vol.60, 2020, No.5, pp.979-987)

1）日本製鉄 (株) 技術開発本部先端技術研究所 (Advanced Technology Research Laboratories, Nippon Steel Corporation)

2）日鉄テクノロジー (株)（Nippon Steel Technology Co., Ltd）

3）高エネルギー加速器研究機構 (KEK) 物質構造科学研究所フォトンファクトリー（PF）（Photon Factory, Institute of Materials Structure Science, High Energy Accelerator Research Organization)

4）総合研究大学院大学高エネルギー加速器科学研究科 (School of High Energy Accelerator Science, SOKENDAI (The Graduate University for Advanced Studies))

* Corresponding author. E-mail : itabashi.53b.daisuke@jp.nipponsteel.com, Address : Nippon Steel Corporation, 20-1 Shintomi Futtsu Chiba 293-8511 
出物や介在物等) の粒子径分布を正確に測定する手法とし て有用であると期待されているが，鉄鋼材料のように構成 相・組織が複雑な材料への適用は，いまだ行われていない。

そこで本研究では，鉄鋼材料の評価に AF4 適用する 方法を検討した。最初に，金ナノ粒子(AuNPs)を用いて， AF4による粒子径分布測定の性能を調査した。AuNPsの平 均粒子径と粒子径分布の分布幅に関して, AF4，TEM およ び小角X線散乱法 (small-angle X-ray scattering; SAXS) の測 定結果を相互比較することによって, AF4による分析の確 からしさを検証した。さらに，これらの結果に基づいて， AF4で測定した粒子径分布を補正するための拡がり係数 (broadening factor) を考案した。最後に, 鉄鋼材料中の二 オブ炭化物 $(\mathrm{NbC})$ を用いて, broadening factorを適用した $\mathrm{AF} 4$ にる鉄鋼材料中の析出物の粒子径分布測定への適用 可能性を調査した。

\section{2. 実験}

\section{$2 \cdot 1$ ナノ粒子および試薬}

実験には金ナノ粒子 (AuNPs, nanoComposix (USA)), 銀 ナノ粒子 (AgNPs, nanoComposix (USA)) およびサイズ標 準ポリスチレンラテックス粒子STADEX (PSL，JSRライ フサイエンス株式会社（日本））を用いた。Table 1 および2 に標準ナノ粒子および試験材の仕様をまとめた。4種類の AuNPs (AuNP-2, AuNP-5, AuNP-7, AuNP-10) を用いて, $\mathrm{AF} 4$ によ粒子径測定の較正曲線を作成した。また, $\mathrm{AF} 4$, TEMおよびSAXSの相互比較にはAuNP-5.5を用いた。 AF4，SAXSでは水中に分散した状態でAuNP-5.5を各々測 定し，TEMでは，AuNP-5.5 の分散液を別途カーボン支持膜 付きグリッドに乗せて乾燥させた後，明視野 (bright field; $\mathrm{BF}$ ）像で観察した。形状の異なる粒子の AF4およびTEM による粒子径分布測定には，2種類の AgNPs（球状打よび 板状，それぞれAgNP-50s，AgNP-50p と以下記す）を使用 した。加えて，各 $\mathrm{AgNPs} の \mathrm{AF} 4$ による粒子径測定では，上 記の AuNPs と PSLを用いて作成した較正曲線を使用した。

AF4では, 追加の精製なしに購入したままの状態で全て の試薬を使用した。試料溶液の希釈と $\mathrm{AF} 4$ キャリア溶液の

Table 1. List of nanoparticles for reference.

\begin{tabular}{ccccc}
\hline Sample & $\begin{array}{c}\text { Average } \\
\text { diameter }(\mathrm{nm})\end{array}$ & $\begin{array}{c}\text { Concentration } \\
(\mathrm{mg} / \mathrm{L})\end{array}$ & Dispersant & Shape \\
\hline AuNP-2 & $2.1 \pm 0.3$ & 52.5 & Glutathione & Sphere-like \\
AuNP-5 & $5.0 \pm 0.6$ & 1080 & Citrate & Sphere-like \\
AuNP-7 & $7.5 \pm 0.8$ & 1070 & Citrate & Sphere-like \\
AuNP-10 & $9.8 \pm 0.8$ & 1080 & Citrate & Sphere-like \\
PSL-29 & $29 \pm 1$ & 5000 & - & Sphere \\
PSL-48 & $48 \pm 1$ & 10000 & - & Sphere \\
PSL-70 & $70 \pm 1$ & 10000 & - & Sphere \\
PSL-100 & $100 \pm 3$ & 10000 & - & Sphere \\
\hline
\end{tabular}

調製には，超純水（>18 M $\Omega$ ：Milli-Q水精製システムおよ びElix UV10, Millipore, USA）を使用した。AF4キャリア 溶液および鉄鋼試料中の析出物分散液の調製には，ドデシ ル硫酸ナトリウム $(\mathrm{SDS}$, 純度 $\geqq 99.0 \%$, 富士フイルム和光 純薬株式会社（日本））を用いた。アセチルアセトン（AA, 特級, 富士フイルム和光純薬株式会社 (日本)), 塩化テト ラメチルアンモニゥム（TMAC, 純度 $\geqq 98.0 \%$, 東京化成工 業株式会社 (日本) ), メタノール（特級, 富士フイルム和光 純薬株式会社 (日本) ) を使用して，鉄鋼試料から析出物を 抽出した。

\section{$2 \cdot 2$ 電解抽出法による鉄鋼材料中析出物の抽出および試 料調製}

$0.1 \mathrm{Nb}-0.01 \mathrm{C}(\mathrm{wt} \%)$ の化学組成を有する $\mathrm{NbC}$ 析出フェラ イト鋼を，真空誘導溶解法によって電解鉄から作製した。 熱処理用のブロック試験片 $\left(30 \times 33 \times 45 \mathrm{~mm}^{3}\right)$ を鋳造し たままのインゴットから切り出して, 溶体化处理 $\left(1250^{\circ} \mathrm{C}\right.$, 24 時間）を施した後に水冷し，その後 $600{ }^{\circ} \mathrm{C} て ゙ 1$ 時間打よ び 10 時間保持することで, $\mathrm{NbC}$ を析出させた。この $600^{\circ} \mathrm{C}$ での熱処理の保持時間を調整することによって, $\mathrm{NbC}$ の粒 子径や個数密度を変化させた。さらに, 試料を $25 \times 25 \times$ $2 \mathrm{~mm}^{3}$ の大きさに切断し, 後に続く分析に供した。

鉄鋼試料中に形成した析出物を電解エッチング (selective potentio-static etching by electrolytic dissolution; SPEED) ${ }^{21}$ 法 によって, 電解液中に抽出して分散させ, 各分析用の試料 とした。電解液には $10 \% \mathrm{AA}$ 系電解液 $(10 \%(\mathrm{v} / \mathrm{v}) \mathrm{AA}-1 \%$ (w/v) TMACーメタノール溶液) に，分散剤としてSDSを $10 \mu \mathrm{g} \mathrm{mL}{ }^{-1}$ の濃度となるように添加したものを用いた。電

Table 2. (a) Sample specifications and (b) an average diameter of each specimen measured by different analyses.

(a)

\begin{tabular}{cccc}
\hline Sample & $\begin{array}{c}\text { Concentration } \\
(\mathrm{mg} / \mathrm{L})\end{array}$ & Dispersant & Shape \\
\hline AuNP-5.5 & 1090 & Lipoic acid & Sphere-like \\
\hline AgNP-50s & 20 & Tannic acid & Sphere-like \\
\hline AgNP-50p & 20 & PVA & Plate-like \\
\hline $\begin{array}{c}\text { NbC precipitates } \\
\text { in steel (NCA5-3) }\end{array}$ & - & SDS & Plate-like \\
\hline $\begin{array}{c}\text { NbC precipitates } \\
\text { in steel (NCA5-1) }\end{array}$ & - & SDS & Plate-like \\
\hline
\end{tabular}

(b)

\begin{tabular}{|c|c|c|c|c|}
\hline \multirow[b]{2}{*}{ Sample } & \multicolumn{4}{|c|}{ Average diameter (nm) } \\
\hline & TEM & $\begin{array}{c}\text { AF4 } \\
\text { (raw data) }\end{array}$ & $\begin{array}{c}\mathrm{AF} 4 \\
\text { (corrected) }\end{array}$ & SAXS \\
\hline AuNP-5.5 & $5.5 \pm 0.5$ & $5.6 \pm 1.0$ & $5.6 \pm 0.5$ & $5.0 \pm 0.2$ \\
\hline AgNP-50s & $52.1 \pm 7.1$ & $54.1 \pm 11.1$ & - & - \\
\hline AgNP-50p & $56.2 \pm 14.6$ & $59.6 \pm 23.0$ & - & - \\
\hline \multirow{2}{*}{$\begin{array}{l}\mathrm{NbC} \text { precipitates } \\
\text { in steel (NCA5-3) }\end{array}$} & $\begin{array}{l}2.4 \pm 1.0 \\
(\text { FOV-1) }\end{array}$ & \multirow{2}{*}{$2.0 \pm 0.4$} & \multirow{2}{*}{$2.0 \pm 0.2$} & - \\
\hline & $\begin{array}{l}2.1 \pm 0.4 \\
(\mathrm{FOV}-2)\end{array}$ & & & - \\
\hline $\begin{array}{l}\text { NbC precipitates } \\
\text { in steel (NCA5-1) }\end{array}$ & - & $2.1 \pm 0.5$ & $2.1 \pm 0.2$ & - \\
\hline
\end{tabular}


解抽出操作では, 電解条件を $500 \mathrm{~mA}$ の定電流電解とし, 以 下に示す2段階のステップで実施した。第1 ステップでは, 試料表面を洗净するための予備操作を行なった。ここで は, 試料表面上の污染や酸化層を溶解するために, 15 分間 の電解抽出操作を行なった。第2 ステップでは, 清浄な試 料の表層から試料 (鉄) のみを溶解するために, 電解抽出 操作を再度行なった。なお, 第1 ステップで使用した電解 液中に溶解した試料表面の污染物質と酸化層を供試料から 取り除くために，第2 ステップでは同一成分を有する別の 電解液に供試料を移した後, 120 分間の電解抽出操作を行 なった。これらの操作により, 約 $1.0 \mathrm{~g}$ の鉄鋼試料 (アノー ド）が電解液中に溶解し，ナノメートルサイズの炭化物を 電解液中に分散した状態で得た。

\section{$2 \cdot 3$ 装置}

\section{$2 \cdot 3 \cdot 1$ AF4-ICP-MS}

Fig.1にWyatt Eclipse AF4 装置 (Wyatt Technology Europe, Germany）の概略図を示す。本装置を後述の ICP-MS 装置に 接続して測定を行なった。本装置は高速液体クロマトグラ フィー用のポンプ，オンライン脱気システムおよびオート サンプラー (Agilent Technologies 1260 Infinity series, Agilent Technologies, USA）を備えている。AF4分離チャネルにナ ノ粒子試料を注入すると, これらの試料はこのチャネル 内で拡散し, チャネルフローによって移動しながら分離 される。この $\mathrm{AF} 4$ 分析では, $10 \mu \mathrm{g} \mathrm{mL}^{-1} \mathrm{SDS}$ 水溶液を AF4

(a)

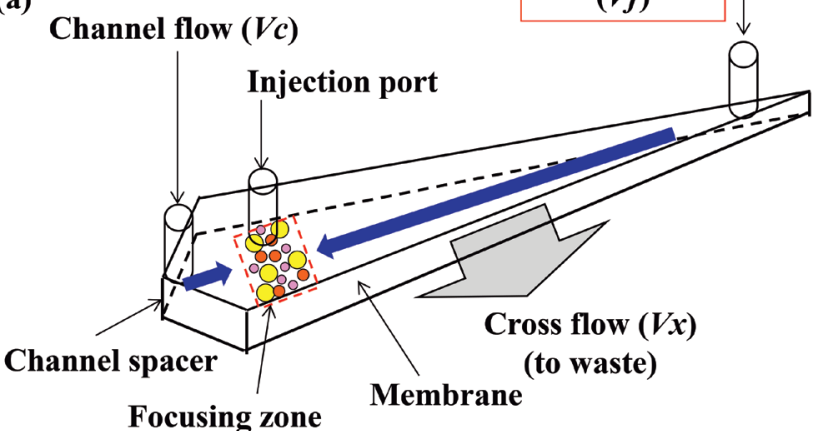
(no net flow)

(b)

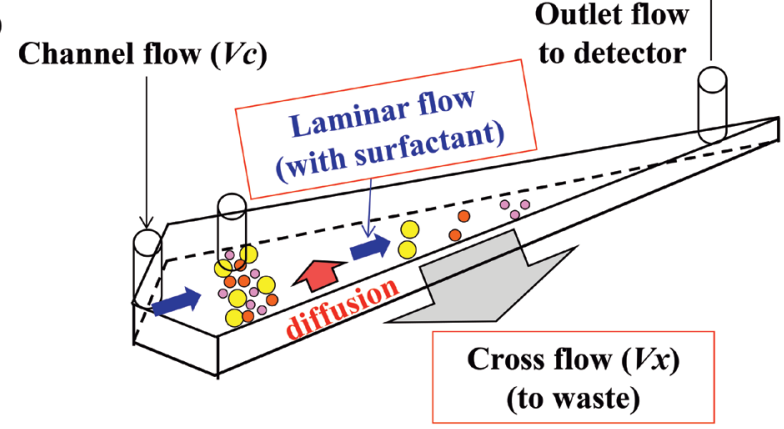

Fig. 1. Schematic of the AF4 instrument. Flow profile observed during the (a) focusing step and (b) elution step. (Online version in color.)
キャリア溶液として用いた。さらに，分子量カットオフ 径 $30 \mathrm{kDa}$ の再生セルロース (RC) 限外ろ過膜 (RC 30kDa, Microdyn-Nadir, Germany) を AF4 分離チャネルの底部に使 用した。次に, AF4 分離装置には長さ $275 \mathrm{~mm}$ のチャネル, 厚さ $490 \mu \mathrm{m}$ の非対称ダイヤモンド型チャネルスペーサー を採用した。PEEKチューブを介して, AF4分離チャネル を可変波長紫外可視光検出器 (UV-vis, Agilent Technologies 1260 Infinity series）に接続し，その検出波長を520 nmも しくは254 nmに設定した。また, AF4システムのUV-vis 検出器の出口に, PEEKチューブ経由で四重極型ICP-MS (Agilent8800, Agilent Technologies, USA) を接続し, AF4で 分離されたナノ粒子の元素情報をオンラインで取得した。

ICP-MSの試料導入には, 自己吸引型のネブライザー (MicroMist nebulizer) を用いた。Table 3 にICP-MSの操作条 件をまとめた。AF4の測定を行なう前に, 少なくとも 30 分 間, SDSを含む AF4キャリア溶液を AF4 分離チャネルに流 し, RC限外ろ過膜を調整した。AuNPs, AgNPsを分散させ た溶液を, それぞれ $25 \mu \mathrm{g} \mathrm{mL}{ }^{-1}$ の濃度となるように超純水 で希釈し, また, 析出物を分散させた電解液 (以下, SPEED 溶液と記す）に関しては，希釈することなしに，それぞれ 調製した。その後，オートサンプラーを使用してこれらの 試料をAF4 分離チャネルに注入し，それぞれ分析を行なっ た。Table 4 にAF4 分離条件をまとめた。

$2 \cdot 3 \cdot 2$ TEM

溶液中に分散させたAuNPsをカーボン支持膜付きグ リッドに置き, 減圧下で乾燥させて調製し, TEM観察に 供した。次に, 電界放出型透過電子顕微鏡 Tecnai F20（FEI Inc., USA）を使用し, 加速電圧 $80 \mathrm{kV}$ の条件下でこれらの 試料を観察した。AuNPs の明視野像を取得し，画像処理ソ フトウェアDigital Micrograph (Gatan Inc., USA) を用いて 処理した後, 500 個の粒子の最大径を手動で測定した。さ らに，上記の SPEED溶液中に抽出した析出物を AuNPs と 同様の方法でTEM観察用に調製し, 高角度散乱暗視野走 查透過電子顕微鏡法 (high-angle annular dark-field scanning transmission electron microscopy; HAADF-STEM）による観 察を行なった。

Table 3. Operating conditions of the inductively coupled plasma mass spectrometry (ICP-MS) when connecting to AF4.

\begin{tabular}{lc}
\hline Agilent8800 ICP-MS & \\
\hline RF power (W) & 1550 \\
Nebulizer flow (L/min) & 1.05 \\
Cooling gas (L/min) & 15 \\
Auxiliary gas (L/min) & 0.90 \\
Sampling depth (mm) & 8 \\
Element $(\mathrm{m} / \mathrm{z})$ & $\mathrm{Au}(197)$ \\
Duration time (s) & 0.10 \\
Spray chamber temperature $(\mathrm{K})$ & 275.15 \\
\hline
\end{tabular}




\section{$2 \cdot 3 \cdot 3$ SAXS}

高エネルギー加速器研究機構 (KEK) のフォトンファク

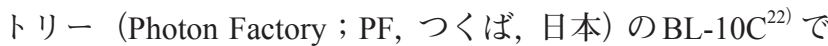
SAXS 測定を実施した。入射X線のエネルギーを $12.4 \mathrm{keV}$ に設定し，二次元ハイブリッド型ピクセル検出器PLATUS3 2M (DECTRIS Ltd., Baden, Switzerland) を試料から $1 \mathrm{~m}$ の 距離に設置した。この測定では，溶液中に分散したAuNPs を測定するために，溶液実験用の特注の試料セルを使用 した。以下にSAXSの測定手順を説明する。AuNPsからの $\mathrm{X}$ 線散乱データを，10秒間の露光時間で 10 フレーム分測 定し，これらを足し合わせることで，ノイズが低減された データを取得した。得られた二次元データをFit2d (ESRF) プログラムを用いて，円環平均して一次元データに変換し た。なお，カメラ距離の較正にはべヘン酸銀 $(\mathrm{I})$ を用いた。 さらに, 散乱べクトル $q$ は以下の式 (1) のように定義され る。

$$
q=\frac{4 \pi}{\lambda} \sin \frac{\theta}{2}
$$

$\lambda:$ 波長 $(\mathrm{nm}), \theta:$ 散乱角

ここで，散乱強度はバックグラウンド散乱を考慮して補正 された值である。

\section{$2 \cdot 4$ AF4の原理の概要}

AF4 分析において，分離シーケンスは試料注入，フォー カシング，緩和，および溶出の4つのステップから構成さ れている ${ }^{23)}$ 。初めに，試料をAF4 分離チャネルに注入して しばらくすると, $\mathrm{AF} 4$ 分離チャネルの水平方向両側からの 流れによって，試料は徐々に一箇所に集められる。このス テップをフォーカシングと呼ぶ (Fig.1 (a))。その後，これ らの試料はAF4 分離チャネルに対して垂直方向，上向きに 拡散し，この拡散距離が試料の粒子径に依存する。すなわ ち，粒子径が小さくなるほど，試料は AF4 分離チャネルの
底部から遠くに拡散することができる。このステップは緩 和と呼ばれている。最後に, 溶出ステップにおいて，チャ ネルフローを一方向のみに変更すると, 層流中の流速の違 いによって試料中の各粒子をそれぞれ分離することができ る（Fig.1（b)）。その結果，より小さな粒子ほど，より速い 保持時間で検出される。この時，試料の保持時間は試料の 拡散係数に従うため, AF4による分離に対して, 試料の拡 散係数は多大な影響を及ぼすことが知られている ${ }^{24)}$

\section{3. 結果と考察}

\section{$3 \cdot 1$ 各ナノ粒子のTEM 観察結果}

初めに, AuNP-5.5, AgNPs，そして鉄鋼試料中の NbCを TEMで観察した。Fig.2にAuNP-5.5 とAgNPsのTEM-BF 像の一例と測定した粒子径分布を示す。その結果, AuNP5.5 と AgNPs は凝集して打らず，一次粒子として単分散し ていることが確認できた。その一方で，Fig.3に示すよう に, $\mathrm{NbC}$ はいくつかの観察視野 (FOVs) で凝集している ことが明らかとなった。粒子の形状に関しては, AuNP-5.5 とAgNP-50s はその大部分が球状であったが，一部の粒子 は球状ではなかった。また, AgNP-50p と NbC は板状であ り，AgNP-50pの直径と厚みはそれぞれ $56 \mathrm{~nm}, 14 \mathrm{~nm}$ 程度， $\mathrm{NbC}$ の直径と厚みは数 $\mathrm{nm}$ であった。これらのナノ粒子の 粒子径を，次の AF4 およびSAXS で測定した。

\section{3・2 AuNPsのAF4, TEM およびSAXSの測定結果の比較 (平均粒子径と粒子径分布の幅)}

AF4による粒子径測定の性能を確認するために, AF4, TEMおよびシンクロトロン放射光を用いた SAXSによっ て, 同一のAuNP-5.5 (一次粒子径 $5.5 \pm 0.5 \mathrm{~nm}$ ) を測定し た。まず初めに, AF4の測定は数 nmのナノ粒子を十分に 分離できるように最適化した条件下で行い，他のAuNPsの 粒子径と保持時間の相関関係に基づいて作成した較正曲

Table 4. Separation condition in AF4.

\begin{tabular}{|c|c|c|c|}
\hline & & For AuNPs and NbC precipitates & For AgNPs \\
\hline \multirow{4}{*}{ Channel parameters } & Membrane nature & Regenerated Cellulose (RC) & Regenerated Cellulose (RC) \\
\hline & Membrane cut-off & $30 \mathrm{kDa}$ & $5 \mathrm{kDa}$ \\
\hline & Spacer & 490 um & $350 \mathrm{um}$ \\
\hline & Elution solvent & $0.035 \mathrm{mmol} \mathrm{L}^{-1} \mathrm{SDS}$ & $1.73 \mathrm{mmol} \mathrm{L}^{-1} \mathrm{SDS}$ \\
\hline \multirow{4}{*}{ Fractionation time } & Elution time & 1 minute & 1 minute \\
\hline & Focusing time & 1 minute & 1 minute \\
\hline & Focusing time & 1 minute & 3 minutes \\
\hline & Elution time & 45 minutes & 35 minutes \\
\hline \multirow{4}{*}{ Fractionation step, flow, and volume } & Injection volume & 20-100 $\mu \mathrm{L}$ (optimal) & $100 \mu \mathrm{L}$ \\
\hline & Injection flow & $0.2 \mathrm{~mL} \mathrm{~min}^{-1}$ & $0.2 \mathrm{~mL} \mathrm{~min}^{-1}$ \\
\hline & Channel flow (Vout) & $1.0 \mathrm{~mL} \mathrm{~min}^{-1}$ & $1.0 \mathrm{~mL} \mathrm{~min}^{-1}$ \\
\hline & Cross flow $(\mathrm{Vc})$ & $2.0 \rightarrow 0.1 \mathrm{~mL} \mathrm{~min}^{-1}$ (linear gradient) & $3.0 \rightarrow 0 \mathrm{~mL} \mathrm{~min}{ }^{-1}$ (linear gradient) \\
\hline Detector & UV absorbance & $520 \mathrm{~nm}$ & $254 \mathrm{~nm}$ \\
\hline
\end{tabular}


線を用いて，AuNP-5.5の粒子径分布を見積った。得られた $\mathrm{AF} 4$ の測定結果をガウス関数でフィッティングし, AuNP5.5 の平均粒子径と粒子径分布の半值全幅 (full width at half maxima; FWHM）を算出した。次に, AuNP-5.5のTEM観察 では，TEMによる粒子径測定の不確かさを確かめるため に, 測定を二度繰り返し行なった。最後に, SAXSの測定 では, AuNP-5.5 の分散溶液を特注の試料セルに入れて, 溶 液中にAuNP-5.5が分散した状態で測定を行なった。Fig.4 に, AuNP-5.5の分散溶液のSAXS プロファイルを示す。そ の結果, 罒中に矢印で示した2つの散乱ピークを明瞭に観
察することができた。一般的に, 試料中の散乱体が均一な 粒子径分布を有する場合には, 形状因子由来の散乱の極大 值が明瞭に観察されることが知られている。したがって, AuNP-5.5 はほぼ均一な粒子径を有していると考えられる。 また, TEM観察の結果から, AuNP-5.5 の形状は球状であ ると推定できるため, 取得したSAXS プロファイルを理論 散乱曲線によってフィッティングした。ここで, 球状粒子 の形状因子 $P(q)$ は, 以下の式 (2) で表現され, $P(q)$ の粒 子径分布に関しては，ガウス分布を用いて作成した。Fig.4 中の実線は，上記の手順で算出したSAXS プロファイルを (a)

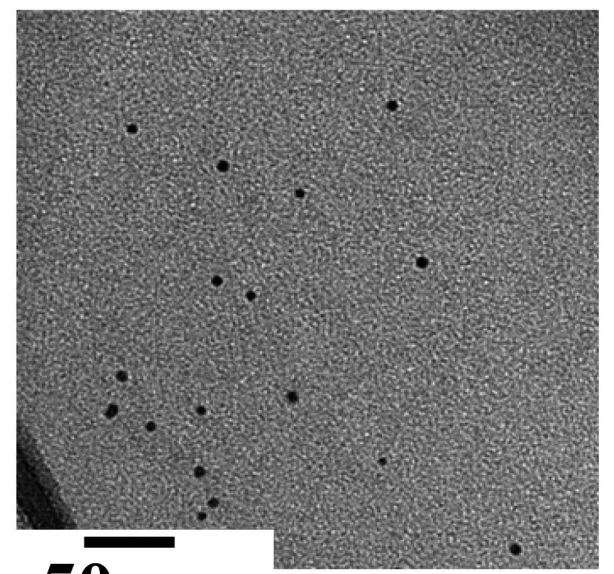

\section{$50 \mathrm{~nm}$}

(c)
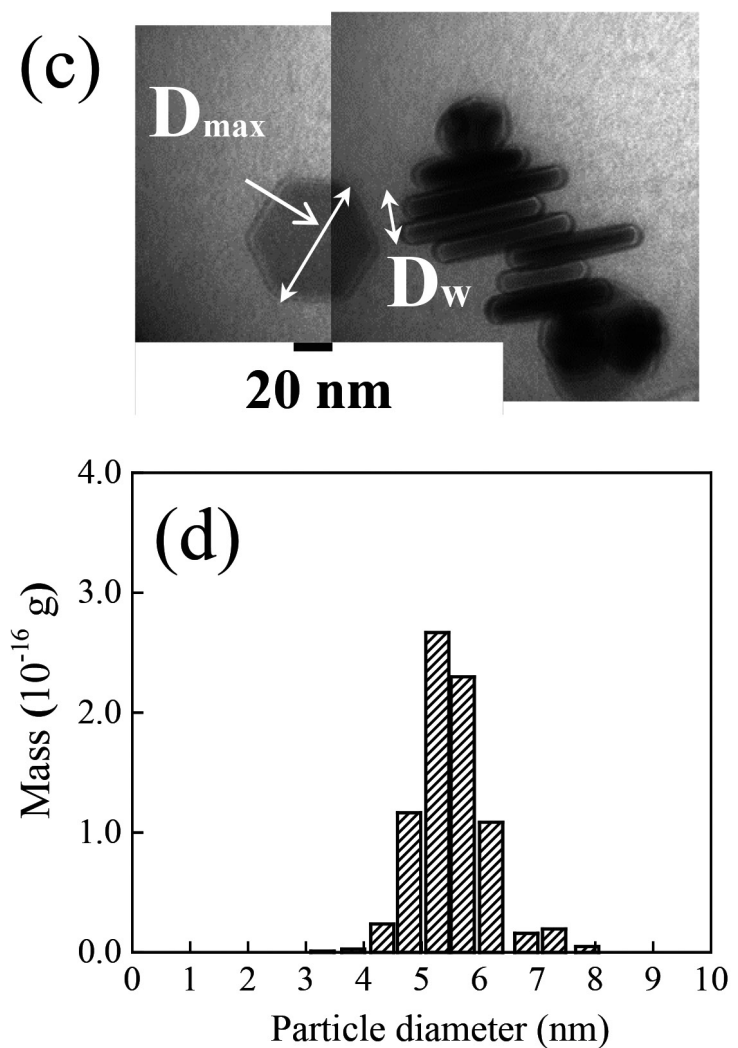

(b)

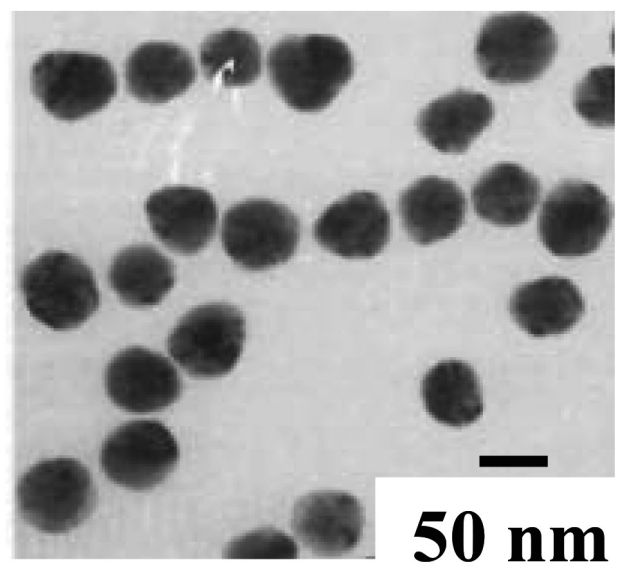

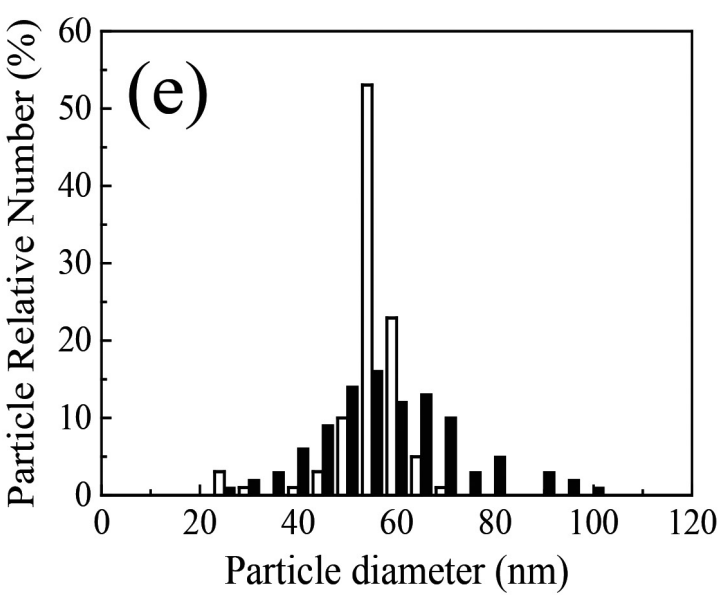

Fig. 2. TEM bright-field image of (a) AuNP-5.5, (b) AgNP-50s, and (c) AgNP-50p on a carbon-supporting grid. The size distribution of (d) AuNP-5.5 and (e) two types of AgNPs by TEM. The white bar shows AgNP-50s and the black bar shows AgNP-50p. The diameter of AgNP-50p was measured as a maximum of diameter $\left(D_{\max }\right)$. The thickness of AgNP-50p $\left(D_{w}\right)$ was ignored here. 
示しており，このSAXSプロファイルは，実験で取得した SAXS プロファイルと非常に良く一致することが明らかと なった。

$$
P(q)=\left(3 C \frac{\sin (q R)-q R \cos (q R)}{(q R)^{3}}\right)^{2}
$$

ここで, $C$ は定数, $R$ は球の半径, $q$ は散乱べクトルの絶対 值である。

Fig.5 (a) にAF4，TEM打よびSAXSによる粒子径測定の 結果を示す。Table 2 にはAuNP-5.5 の平均粒子径と粒子径 分布のFWHMをそれぞれまとめた。まず, AF4とTEMで それぞれ求めた平均粒子径を比較すると，予想した通り に両者は一致した。これはAF4に打ける粒子径の算出が TEMの測定結果に基づいた粒子径の較正曲線を使用して いるためであると考えられる。しかし, AF4 と TEMで求め た二つの平均粒子径はSAXS で求めた值よりも僅かに大き かった。この違いは粒子の形状に関する仮定に起因すると 考えられる。今回のSAXSの測定結果の解析では, AuNPs

\section{(a)}

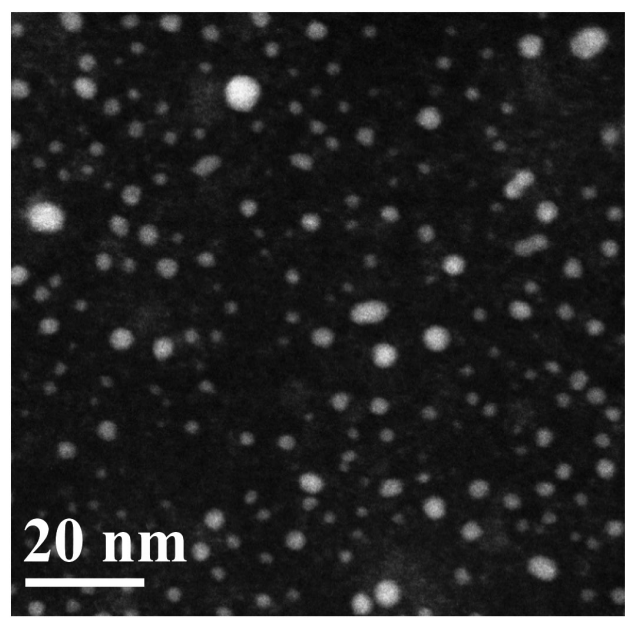

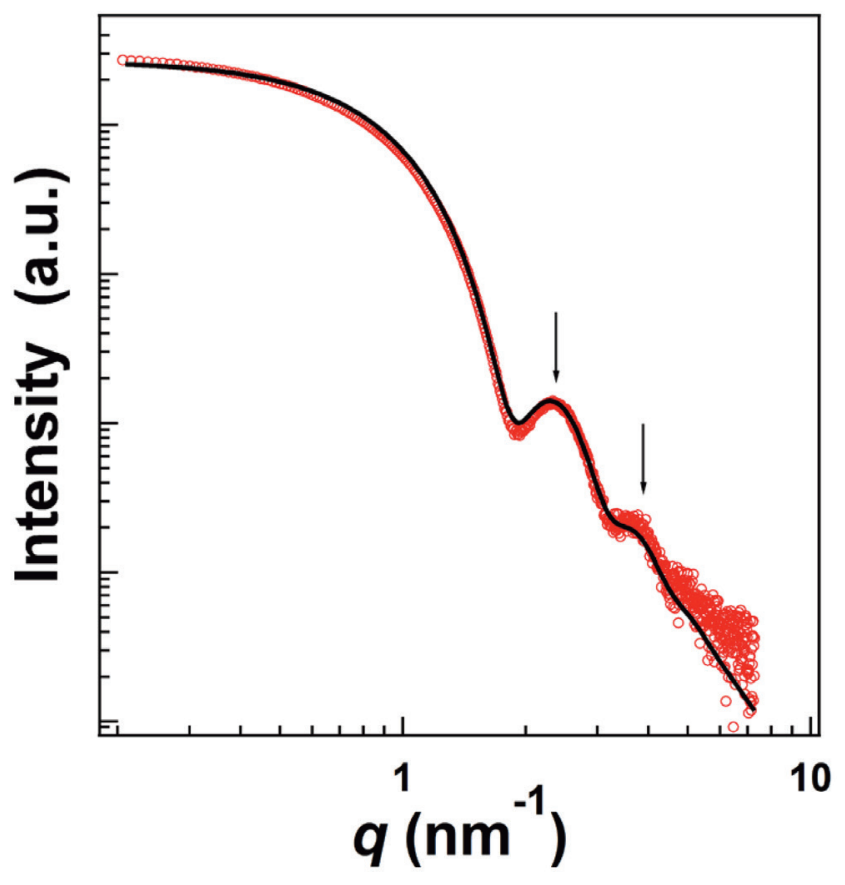

Fig. 4. SAXS profile of $5.5 \pm 0.5 \mathrm{~nm}$ AuNPs. Solid line represents the model fits obtained using Eq. (2). (Online version in color.)

(b)
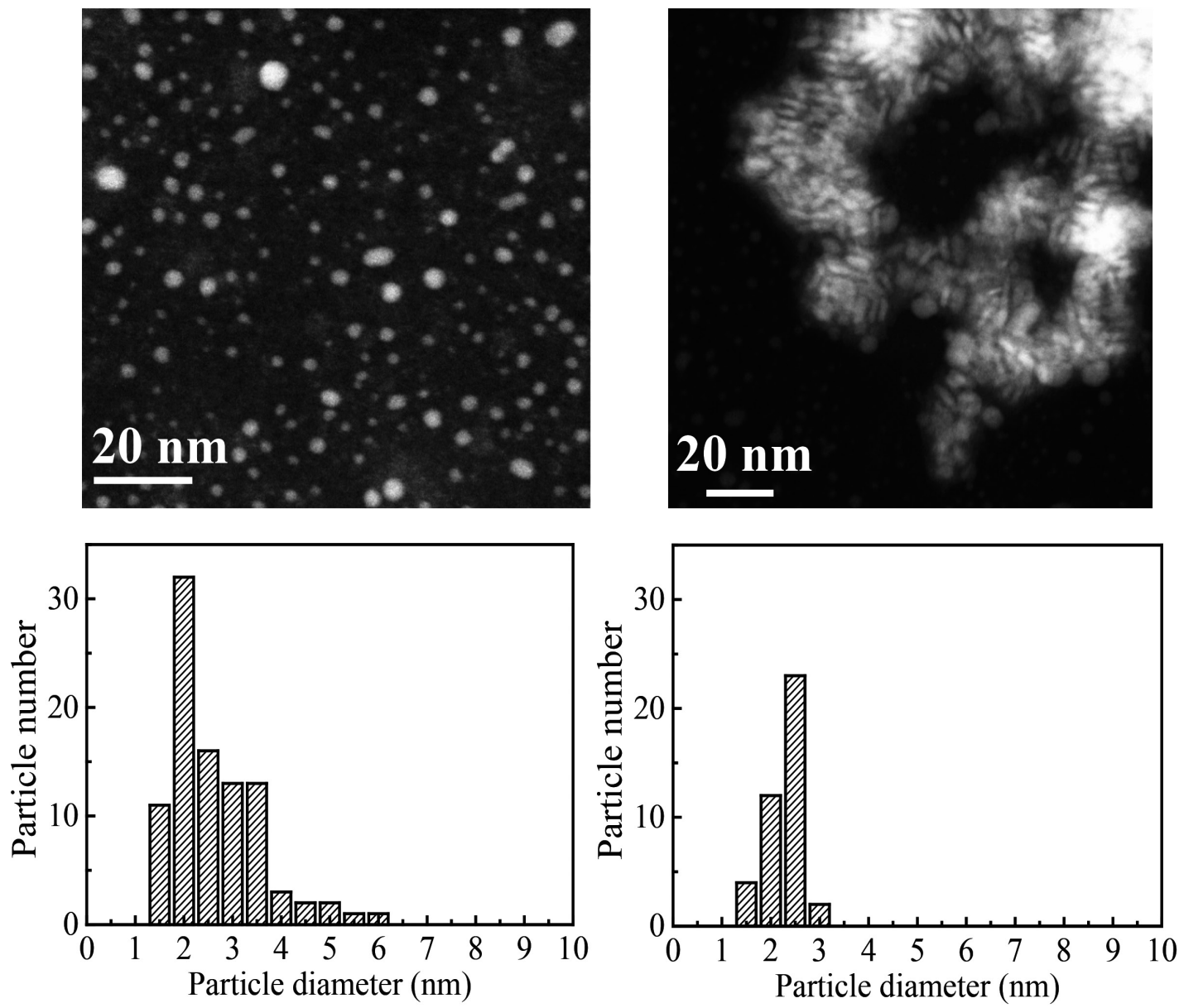

Fig. 3. HAADF-STEM image of electrolytically extracted NbC from the steel sheet, NCA5-3, at two FOVs and size distributions at each FOV: (a) FOV No.1 and (b) FOV No.2. 
の形状は完全な球状であると仮定したが，実際に測定し たAuNPsは完全な球状ではなかったことがTEM観察の結 果から明らかとなって抢り，この差が影響したと考えられ る。

次に, 粒子径分布のFWHMをそれぞれ比較すると, AF4 の測定結果はTEM PSAXS の測定結果と一致しなかった。 今回, AF4で測定した粒子径分布のFWHMはSAXSで得 られた值のほぼ5倍であり，TEMで得られた值の約 2 倍で あった。これらの違いは，以下の2つの理由によるもので あると考えられる。第一に, 今回用いた粒子のキャラクタ リゼーションは，それぞれ異なる原理の測定法を複数用
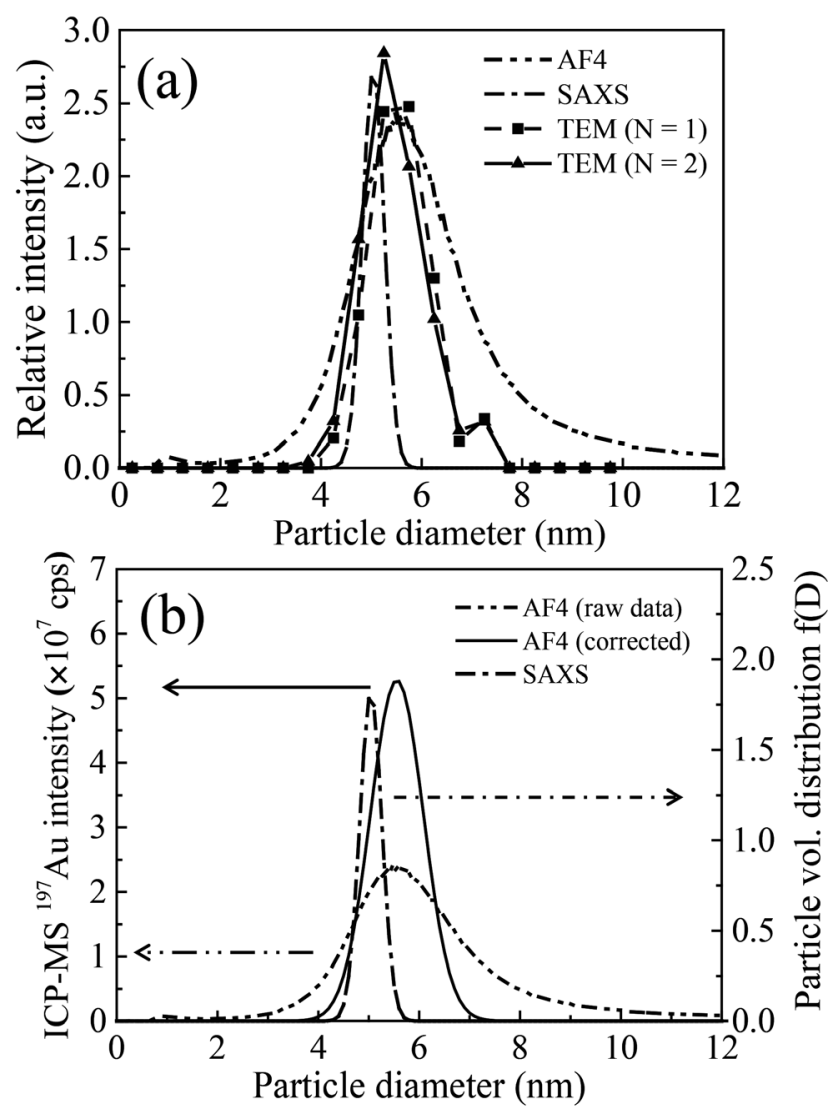

Fig. 5. (a) Size distributions of AuNP-5.5 measured using AF4, TEM, and SAXS. The AF4 was operated under optimized conditions. TEM observations were repeated twice. (b) Comparison of size distributions of AuNP-5.5 among AF4, AF4 with broadening factor, and SAXS.
いて行った。AF4は粒子の移動度, TEMは電子線の回折, SAXS はX線による結晶学的な電子密度の差からの散乱, という異なる原理で測定している。そのため, AF4の測定 結果は粒子の最外部の形状・大きさを反映しており, TEM の測定結果は元素組成や結晶性に由来する電子線の回折コ ントラストを示し, SAXSの測定結果は粒子と周囲のマト リックスの間の電子密度の違いを示している。ゆえに, 粒 子の形状に関する仮定の違いが，これらの結果に反映され たと考えられる。

第二に, AF4で測定した粒子径分布のFWHMは, AF4分 離チャネル内に打ける粒子自身の拡散によって, 他の手法 よりも大きな值になったと考えられる。なぜならば, AF4 による測定は粒子が流れている状態で行われるため, AF4 分離チャネル内で粒子自身が拡散してしまうことは避け られない。この拡散によって粒子径分布が真值よりも拡が り, その結果, サイズ分解能が低下するため, AF4を利用 した粒子径分布の測定方法には改善の必要があると考えら れる。

\section{3・3 AF4 分析における粒子径分布幅の補正}

$3 \cdot 2$ 項で説明したように, 粒子径分布のFWHMは測定 原理に大きく依存するため, AF4の測定結果を他の解析 手法に対して補正する方法を検討した。考案した $\mathrm{AF} 4$ の 粒子径分布測定における FWHMの補正は以下の通りであ る。AuNP-5.5の粒子径分布に関して，TEMまたはSAXSの FWHMに対するAF4のFWHMの比を，それぞれTable 2 に 示した結果から計算した。その結果, AF4/SAXS, AF4/TEM のFWHM比はそれぞれ4.64打よび1.94であった。ここで， $\mathrm{AF} 4$ の粒子径測定の較正においては, TEMを使用して求め た粒子径を用いているため, AF4/TEMのFWHM 比を補正 に採用するべきであると考え，この值を AF4分析に打ける broadening factor として定義した。加えて，上記と同様にし て, 他のナノ粒子に対する broadening factorを計算した結 果を Table 5 に示す。なお，2種類の AgNPs は上記の AuNPs と比較して粒子の直径が 10 倍程度大きかったため, 別の $\mathrm{AF} 4$ 測定条件下で測定した。加えて, AF4による $\mathrm{AgNPs} の$ 測定を行なう前に，いくつかのAuNPs およびPSL粒子を 用いて粒子径測定の較正曲線を作成した（Fig.6）。AF4 打 よびTEMによって測定した 2 種類の AgNPs の粒子径分布

Table 5. The broadening factors in AF4 analysis.

\begin{tabular}{|c|c|c|c|c|c|c|c|}
\hline Samples & $\begin{array}{l}\text { Average size/nm } \\
\text { (TEM) }\end{array}$ & Shape & $\begin{array}{l}\text { Component of } \\
\text { materials }\end{array}$ & Density $/ \mathrm{g} \cdot \mathrm{cm}^{-3}$ & $\begin{array}{c}\text { Broadening } \\
\text { coefficient }\end{array}$ & FWHM (AF4) & FWHM (TEM) \\
\hline AuNP-2 & $2.1 \pm 0.3$ & sphere-like & Gold & 19.32 & 2.21 & 1.66 & 0.75 \\
\hline AuNP-5 & $5.0 \pm 0.6$ & sphere-like & Gold & 19.32 & 2.05 & 2.56 & 1.25 \\
\hline AuNP-5.5 & $5.5 \pm 0.5$ & sphere-like & Gold & 19.32 & 1.94 & 2.40 & 1.24 \\
\hline AuNP-7 & $7.5 \pm 0.8$ & sphere-like & Gold & 19.32 & 2.29 & 3.09 & 1.35 \\
\hline AuNP-10 & $9.8 \pm 0.8$ & sphere-like & Gold & 19.32 & 1.94 & 3.47 & 1.79 \\
\hline AgNP-50p & $56.2 \pm 14.6$ & plate-like & Silver & 10.49 & 1.64 & 54.05 & 32.90 \\
\hline
\end{tabular}


をFig.7に示す。その結果, AF4分離チャネル内での粒子 の拡散は, 粒子径に関係なく, AF4クロマトグラムに影 響を与える可能性があることが明らかとなった。ここで, broadening factorに対して得られた知見を以下にまとめた。

(i) 上記の AuNPsの測定結果から計算された broadening factor は, 粒子の形状や種類に大きく依存する。球状 の粒子に対して決定された broadening factor は, 1.94〜 2.29 の範囲内であった。

(ii) 異なる種類の粒子間の直接比較は容易ではないため, 2 種類の AgNPsに対して, 粒子形状の影響を以下の通 り考察した。板状の粒子に対する broadening factorは, 球状の粒子に対する broadening factorよりも見かけ上 小さくなった。これは, AF4分離チャネル内の流れが 板状の粒子自身のブラウン拡散よりも支配的になると いう事実に起因して打り, 只の結果として, 板状の粒 子のブラウン運動が $\mathrm{AF} 4$ 分離チャネル内の流れに対し

て，水平方向に抑制されたと考えられる。

続いて, 上記の broadening factorを使用して, AF4で測定 したAuNP-5.5の粒子径分布の標準偏差の補正値を計算し, これに加えて求めた平均粒子径, 検出したピークの総面積 を用いて, AF4で測定した粒子径分布の補正を行なった。 この際には, TEMおよびSAXSの測定結果からガウス分布 を仮定した。broadening factorによって補正したAuNP-5.5 の粒子径分布の AF4測定結果を Fig.5（b）に示す。TEMに よって較正された AF4の測定結果は, SAXSの測定結果に 近しくなることが明らかとなった。

\section{$3 \cdot 4$ broadening factorを適用したAF4による粒子径分布 測定法の鉄鋼材料中 $\mathrm{NbC}$ への応用}

AF4 分析に打ける FWHMの補正の適用可能性を調查す るために, 鉄鋼試料から抽出した $\mathrm{NbC}$ を $\mathrm{AF} 4$ で測定した。 その結果, FWHMの補正は, 鉄鋼材料中のナノメートルサ イズの析出物の粒子径をより精度良く測定するのに, 効果

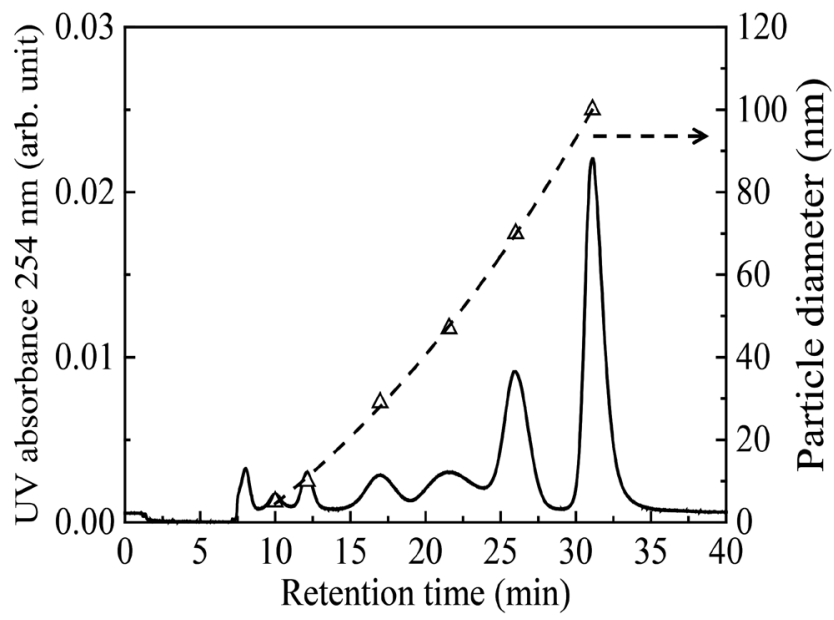

Fig. 6. Separation results of AuNPs and PSL mixtures by AF4. Bottom and right axes show the size calibration curve.
的であることが分かった。

まず, AuNPs と同一のAF4測定条件でNbCを測定した。 Fig.8にAF4で測定した $\mathrm{NbC}$ の粒子径分布を示す。これら
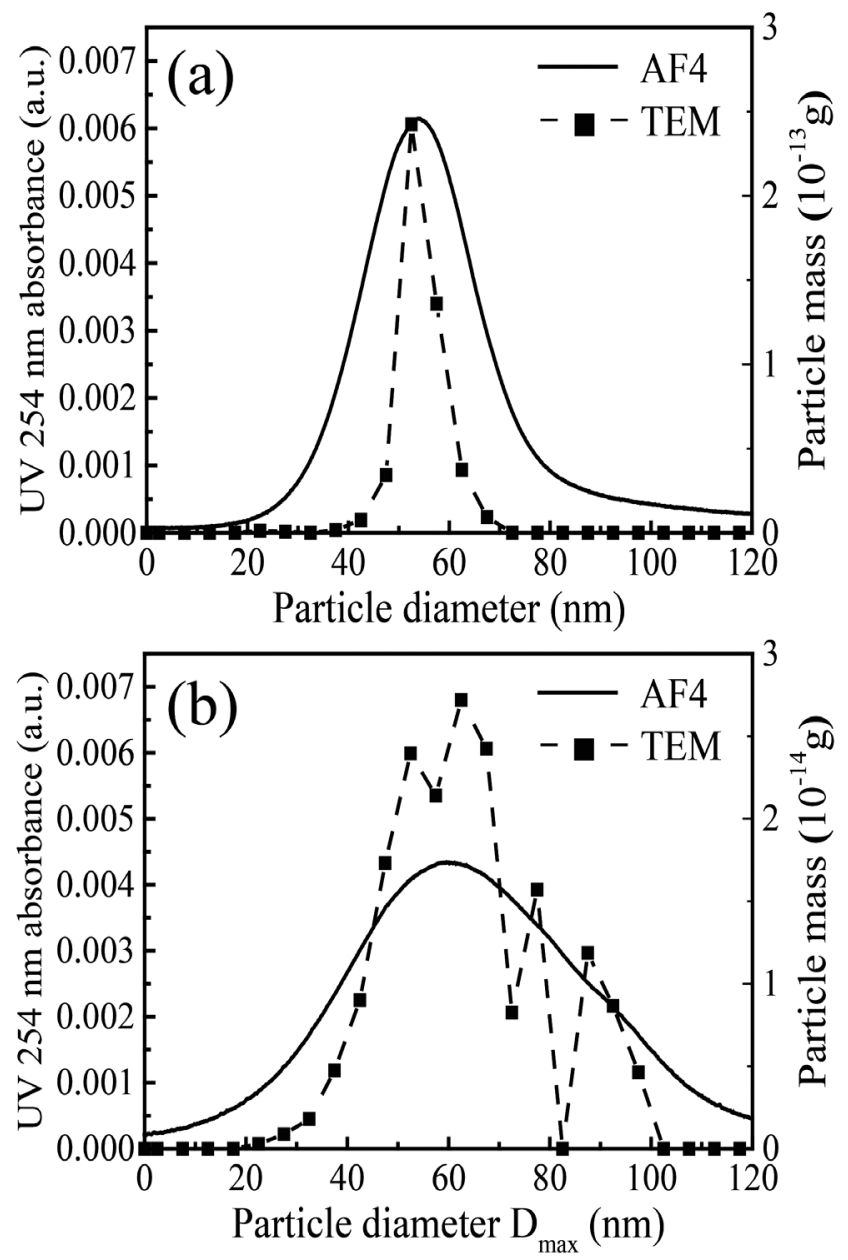

Fig. 7. Size distributions of AgNPs measured using TEM and AF4. (a) AgNP-50s and (b) AgNP-50p.

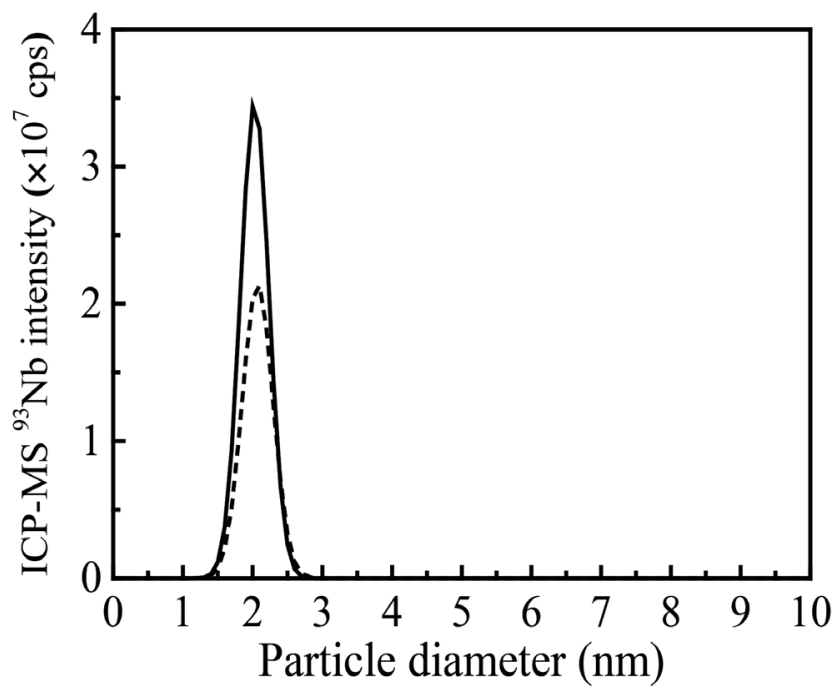

Fig. 8. Results of AF4-ICP-MS measurement for $\mathrm{NbC}$ in steels. The heat treatment was processed at $873 \mathrm{~K}$ to NCA5-1 (dotted line) for $1 \mathrm{~h}$ and to NCA5-3 (straight line) for $10 \mathrm{~h}$. 
の試料への熱処理は, $\mathrm{NbC}$ の粒子径を増大させるために施 して打り，NCA5-3の粒子径の方が大きくなると想定され る。また, これらの NbCをTEMで観察したところ, 鋼板試 料中に不均一に分散していることが分かった。 $\mathrm{NbC}$ の粒子 径分布は，いくつかのFOVsの間で一致していなかったが, $\mathrm{AF} 4$ は粒子径分布に関する平均的な情報を示しており, こ れらの結果はTEMの結果にほほ近かった。加えて,これら の結果から我々の予測に反して, 熱処理の保持時間の増加 とともに $\mathrm{NbC}$ の粒子径ではなく, 個数密度のみが約 1.5 倍 に増加することが明らかとなった。なお, AF4-ICP-MSの 定量性には改善の余地があるため, この研究では定量分析 は行なっていない。しかし, AF4-ICP-MSで取得したピー ク面積は $\mathrm{NbC}$ の相対的な量を示しているため, NCA5-1 と NCA5-3の間でピーク面積を比較することによって, $\mathrm{NbC}$ の個数密度の差を相対的に議論することができると考え た。両者のピーク面積を計算したところ，それぞれ 1.0 と 1.5であった。このように, AF4-ICP-MS は鉄鋼材料中の析 出物を半定量的に測定するのに効果的であることが分かっ た。

結論として,AF4分析に打ける粒子径分布のFWHMの 補正は，様々なナノ粒子を評価するのに有用であることが 分かった。今後は，粒子径分布のFWHMへの粒子の形状の 影響をさらに考慮した解析手法を検討し，また，AF4-ICPMSに打ける定量分析法を改善することによって, より詳 細な議論が可能になると考えられる。

\section{4. 結言}

様々なナノ粒子を用いて，TEMを伴った AF4による粒 子径分布の測定方法を検討した。この研究で得られた知見 を以下に示す。

(1) AF4で測定した平均粒子径はTEM およびSAXS で測定 した平均粒子径とほぼ同じであった。

(2) AF4の測定では, AF4分離チャネル内で粒子自身が拡 散したために,ピークの拡がり現象が起こった。

(3) AF4 分析に打ける粒子径分布のFWHMの補正は, AF4/ TEMのFWHM比として定義される broadening factorを 用いることにより可能であることが確認できた。

(4) 球状の粒子に対する broadening factor は約 2.0 と決定さ れたが，その一方で，板状の粒子に対する broadening factor（約 1.6）はブラウン運動の抑制によって, 見かけ 上球状の粒子の值よりも小さくなった。

以上の結果から, broadening factorを適用することによ り, AF4 分析は様々なナノ粒子の粒子径の評価に対して有
効となり, AF4 分析における FWHMの補正の適用可能性 が示された。

謝辞

本研究の一部は,「フォトンファクトリーにおける産業 利用促進」の制度のもと，フォトンファクトリーのスタッ フのご協力を得て，実施されました(課題番号2014I003)。 スタッフのご協力に感謝致します。

\section{文献}

1 ) K.S.Siddiqi and A.Husen: J. Trace Elem. Med. Biol., 40(2017), 10.

2 ) D.Peng, B.Hu, M.Kang, M.Wang, L.He, Z.Zhang and S.Fang: Appl. Surf. Sci., 390(2016), 422.

3 ) H.Chen, F.Gao, R.He and D.Cui: J. Colloid Interface Sci., 315(2007), 158.

4 ) Y.Li and F.Zaera: J. Catal., 326(2015), 116.

5 ) T.Jamieson, R.Bakhshi, D.Petrova, R.Pocock, M.Imani and A.M.Seifalian: Biomaterials, 28(2007), 4717.

6 ) N.Kamikawa, Y.Abe, G.Miyamoto, Y.Funakawa and T.Furuhara: ISIJ Int., 54(2014), 212.

7 ) T.Kataoka, Y.Arita, F.Takahashi, H.Fujimura, Y.Kurosaki, M.Sugiyama and I.Ohnuma: ISIJ Int., 56(2016), 2062.

8 ) M.Filella, J.Zhang, M.E.Newman and J.Buffle: Colloids Surf. A, 120(1997), 27.

9 ) K.Tiede, A.B.A.Boxall, S.P.Tear, J.Lewis, H.David and M.Hassellöv: Food Addit. Contam. Part A., 25(2008), 795.

10) M.Hasselloev and R.Kaegi: Environmental and Human Health Impacts of Nanotechnology, ed. by J.R.Lead and E.Smith, Wiley Interscience, Bognor Regis, (2009), 211.

11) G.T.Wei, F.K.Liu and C.R.Chris Wang: Anal. Chem., 71(1999), 2085.

12) K.M.Krueger, A.M.Al-Somali, J.C.Falkner and V.L.Colvin: Anal. Chem., 77(2005), 3511.

13) E.P.Gray, T.A.Bruton, C.P.Higgins, R.U.Halden, P.Westerhoff and J.F.Ranville: J. Anal. At. Spectrom., 27(2012), 1532.

14) F.K.Liu, F.H.Ko, P.W.Huang, C.H.Wu and T.C.Chu: J. Chromatogr. A, 1062(2005), 139.

15) X.Xu, K.K.Caswell, E.Tucker, S.Kabisatpathy, K.L.Brodhacker and W.A.Scrivens: J. Chromatogr. A, 1167(2007), 35.

16) J.C.Giddings: Science, 260(1993), 1456.

17) J.C.Giddings, F.J.Yang and M.N.Myers: Science, 193(1976), 1244.

18) M.Hassellöv, B.Lyvén, C.Haraldsson and W.Sirinawin: Anal. Chem., 71(1999), 3497.

19) B.Schmidt, K.Loeschner, N.Hadrup, A.Mortensen, J.J.Sloth, C.B.Koch and E.H.Larsen: Anal. Chem., 83(2011), 2461.

20) H.Hagendorfer, R.Kaegi, J.Traber, S.F.L.Mertens, R.Scherrers, C.Ludwig and A.Ulrich: Anal. Chim. Acta, 706(2011), 367.

21) K.Takimoto, Y.Taguchi and R.Matumoto: J. Jpn. Inst. Met., 40(1976), 834 (in Japanese).

22) N.Igarashi, Y.Watanabe, Y.Shinohara, Y.Inoko, G.Matsuba, H.Okuda, T.Mori and K.Ito: J. Phys. Conf. Ser, 272(2011), 012026.

23) H.Kato: AIST Bull. Metrol., 6(2007), 185 (in Japanese).

24) M.E.Schimpf, K.Caldwell and J.C.Giddings: Field-Flow Fractionation Handbook, Vol.1, A John Wiley \& Sons, New York, (2000), 1 . 